Article

\title{
Perceptions of Multiple Stakeholders about Environmental Issues at a Nature-Based Tourism Destination: The Case of Yakushima Island, Japan
}

\author{
Ifeoluwa Bolanle Adewumi ${ }^{1, *}$, Rie Usui ${ }^{2}$ and Carolin Funck ${ }^{1}$ \\ 1 Graduate School of Integrated Arts and Sciences, Hiroshima University, 1-7-1 Kagamiyama, \\ Higashihiroshima, Hiroshima 739-8521, Japan \\ 2 Graduate School of Letters, Hiroshima University, 1-2-3 Kagamiyama, Higashihiroshima, \\ Hiroshima 739-8522, Japan \\ * Correspondence: ifykay999@yahoo.com
}

Received: 29 June 2019; Accepted: 5 August 2019; Published: 7 August 2019

\begin{abstract}
The success of nature-based tourism destinations depends on the sustainable use of common pool resources (CPRs). More often than not, tourism demands compete for these resources, exerting pressure on them, resulting in decline of the CPRs. Managing tourism and environmental resources has become extremely important, but also more complex, as the interests of different stakeholders are intertwined across international, national, and local levels. Hence, this study aimed to investigate how stakeholder groups perceive the issues relating to the environment using Yakushima Island, Japan for a case study. Quantitative data were collected by administering a questionnaire to residents and tourism practitioners, while qualitative data were gathered through semi-structured interviews conducted with organizations involved with tourism and environmental management in Yakushima. The study reveals that the underlying environmental issues in Yakushima result from an increase in tourists and controversial management of deer populations. Both residents and tourism practitioners indicated that more trash in the community was the most significant impact of tourism on the environment. Some perceptions were contradictory. Management authorities noted an increase in the deer population, which needs to be controlled to prevent damage to natural vegetation. Most tour guides reported a decrease in the sighting of deer along hiking trails, frustrating the genuine expectations of the tourist. The connection of the deer issue to tourism turned out to be very complex, as an overabundance of deer endangers parts of the vegetation tourists come to enjoy, while at the same time deer are an important part of the tourists' experience. Different perceptions on deer by different stakeholders add to this complexity, which needs to be taken into consideration for proper management of tourists and deer in the future.
\end{abstract}

Keywords: Yakushima Island; Jomonsugi; resource overuse; perception; environmental issues; nature-based tourism destination; common pool resources

\section{Introduction}

Nature-based tourism (NBT) is one of the fastest growing tourism sectors [1,2]. As the popularity increases and tourism activities exert a number of pressures on the natural environment on which NBT relies, many destinations face challenges in sustaining their ecological resources [2,3]. Often, the majority of such resources are considered to be common pool resources (CPRs) [4], meaning they are no one's personal resources, but instead are everyone's shared resources. Thus, exploitation of these resources can generate conflicts if one's short-term interests do not match with the long-term interests of another party [5]. 
More often than not, congestion at NBT destinations results in a decline of CPRs, which can lead to exhaustion and extinction of the resources, unless the visitation rate to the destination is controlled to a certain degree below the limit of the environmental carrying capacity [6]. Cases of habitat changes, degradation and loss, and wildlife disturbance have been widely reported as some of the issues faced by NBT destinations [7,8]. In Mamirua Sustainable Development Reserve Brazil, an overcapacity of tourists has been reported to cause negative impacts on the environment of the reserve [9]. Jaffe reported a drastic reduction in the local penguin population due to disturbance caused by tourists visiting the Chilean island of Dama [10]. In addition, over-visitation of tourists to beaches of Tortuguero in Costa Rica led to increase garbage problems at the turtle sanctuary [11]. Hence, mass tourism at NBT destination can ruin the destination's natural resources if it is not properly managed.

NBT destinations are ecological representatives of a living system where biodiversity interacts and creates a series of biological phenomena, which serve as a basic source for tourism development [8]. However, human needs sometimes enter into competition with nature and wildlife at these destinations $[12,13]$. For example, vegetation of a destination serves as a source of tourism attraction and also habitat and a source of food for wildlife. Hence, conflicts arise in the competition between human and wildlife demands for the same declining resources [14]. In NBT destinations, there are cases where the use of CPRs by wildlife has led to the destruction of resources upon which other users depend. Overgrazing by deer has been reported to endanger vegetation composition and forest succession [15,16]. Asnani et al. revealed that over-browsing by deer in Sharon Woods Metro Park, Ohio caused a decrease in plant abundance and a change in plant species composition [17]. Deer grazing in a Larch Forest in Okutama, Tokyo reduced plants and subsequently lowered habitat quality for Carabid beetles [18]. In Royal National Park, New South Wales, localized soil erosion was associated with deer [19].

In most cases, discourse at NBT destinations revolves around issues of how to meet the need of tourism and at the same time manage the nature of the destination. An important step in resource management at NBT destinations is to assess perceptions of stakeholders [20,21]. Large bodies of research have indicated that studying the perceptions of the stakeholders will help identify problems associated with tourism at a destination and potential solutions [22]. Tourism stakeholders are "any individuals or groups involved, interested in, or affected positively or negatively by tourism" [23] (p. 4). Typically, the four major tourism stakeholders are residents, tourism practitioners, tourists, and local governmental officials [24,25]. For the purpose of this study, residents, tourism practitioners-people involved in tourism related businesses_-and governmental officials were considered. Previous studies comparing multiple stakeholders have revealed differences in perceptions between stakeholders: residents and entrepreneurs [26], residents, entrepreneurs, and governmental officials [24,27]. Such differences in perceptions can be influenced by values and ecological, economic or cultural references [22,28], which are likely formed through the past events that people have experienced [29,30]. Thus, a lack of contextualization in local environmental issues can lead to failure in solving the problems. Therefore, this study aimed to disentangle the complex web of interests existing in environmental debates by unravelling perceptions of different stakeholders, while at the same time contextualizing the environmental issues that NBT destinations have undergone.

Generally, national parks (NPs) are among the major resources and attractions for NBT [31]. Most especially, NBT in Japan is associated with travels to NPs [32]. Since Japanese NPs were designated with the intention of enabling nature tourism, they contain the most popular tourist destinations in the country [33,34]. Over time, NBT in NPs turned to mass tourism, resulting in adverse impacts on the natural environment [33]. Yakushima Island chosen for this study is a NP and a famous NBT destination in Japan. It was inscribed as one of the first The United Nations Educational, Scientific and Cultural Organization (UNESCO) World Natural Heritage Sites (WNHS) in Japan for its unique vegetation and an abundance of Yakushima cedar trees (Yakusugi), Cryptomeria japonica. After its registration as a WNHS, tourist numbers doubled from 209,219 at the point of registration in 1993 to 406,387 in 2007. In the following ten years, an average of 280,000 tourists visited the island annually. The main 
attraction of the island is hiking to Jomonsugi, the island's oldest Yakusugi. Although seasonal, sea turtle viewing is another popular activity during summer. Like many other NBT destinations, an increase in the number of tourists has generated several issues in Yakushima: congestion around Jomonsugi, which harmed the tree itself; disposal of sewage from toilets in mountain areas [35]; resource overuse in the mountain areas, resulting in trampling and damage of vegetation [36,37]. In Yakushima, people also compete with wildlife such as the Yaku sika deer (Cervus nippon yakushimae) over the use of CPRs. Although the Yaku sika deer constitutes an attraction for the tourist, an overabundance of Yaku sika deer causes heavy damage to the natural vegetation and the failure of vegetation to regenerate [38,39], while also harming agricultural production.

Due to the adverse influences of tourism and deer population increases on the natural environment of Yakushima, efforts have been made in managing both issues. However, balancing tourism and environmental management in Yakushima has become a great challenge as the interests of different stakeholders are intertwined across international, national, and local levels. Despite the emphasis placed on comparing the perception of multiple stakeholders in NBT, there has been no such research in Yakushima. Prior studies in Yakushima have focused on perceptions of individual stakeholder groups such as residents [40-42], tourists [43,44], and people involved in tourism businesses [45]. Therefore, the purpose of this study was to examine the environmental issues in Yakushima by focusing on perceptions of multiple stakeholders: residents, tourism practitioners, and management organizations.

Another point missing from the existing research in Yakushima is contextualization of the environmental issues. As we explained, understanding what a certain NBT destination has undergone is an important step in providing a better insight into why people perceive particular environmental issues the way they do. Hence, this research first reviews the past environmental issues in Yakushima using reports, the scientific literature and national media over the last 20 years, covering the period of tourism growth and stabilization. Then, we explore stakeholders' perceptions of the environment in Yakushima by using both quantitative and qualitative approaches. The mixed method approach was adapted because: (a) Yakushima's perception studies have relied heavily on a quantitative approach; and (b) while the quantitative approach has its own strength, it falls short in understanding in depth about stakeholders' perception. It is expected that the results of this study will contribute to providing insights into perceptions of multiple stakeholders about environmental issues occurring at NBT destinations due to competition for the use of CPRs between humans and nature.

\section{Materials and Methods}

Yakushima Island is a subtropical island located in Kagoshima Prefecture, in the southern part of Japan. It has an area of $504.88 \mathrm{~km}^{2}$, with about $80 \%$ of its area covered by forest protected under several conservation legislations such as, National forest, Yakushima National Park, Biosphere Reserve, Wilderness Area, Forest Ecosystem Reserve and World Natural Heritage Site [46] (Figure 1). The island consists of 24 communities and a relatively stable population of around 13,000 inhabitants.

This study adopted a mixed methodological approach including quantitative and qualitative techniques for the data collection. It also took a longitudinal approach by analyzing scientific papers and media reports on environmental issues in Yakushima over several years. Finally, we combined results of fieldwork research conducted by the three authors between 2015 and 2017 and extracted results connected to environmental issues and their perceptions that have not been published before. Through this method, it was possible to cover the perceptions of multiple stakeholders.

The quantitative survey based on a questionnaire, was used to examine the perceptions of residents and tourism practitioners about the impacts of tourism on the environment. The questionnaire administered to both residents and tourism practitioners comprised four main sections, from which two were analyzed and presented in the current paper. The first section included questions on socio-demographic characteristics of respondents. The second section focused on respondents' perceptions towards the impacts of tourism using 20 items measured on a five-point Likert scale (1-strongly disagree to 5-strongly agree), out of which 6 items relating to environmental impacts were 
used for this paper. A purposive sampling technique was used to select the seven communities for this study based on the level of tourism activities. The seven communities selected are Miyanoura, Koseda, Anbo, Onoaida, Hirauch, Kurio, and Nagata. The tourism practitioners' questionnaire was administered in June 2015, while the resident survey was carried out between August and November 2015. Using the membership list of tourism businesses registered with Yakushima Tourism Association as of 2015, a total of 150 businesses in the seven communities were randomly selected. Residents were selected using systematic random sampling, by selecting all houses in streets chosen randomly from the street map coordinates. A total of 800 questionnaires with a return self-addressed envelope were distributed. A total of 114 tourism questionnaires were returned, indicating a response rate of around $76 \%$, and 197 resident questionnaires were properly filled and returned, accounting for $24.75 \%$.

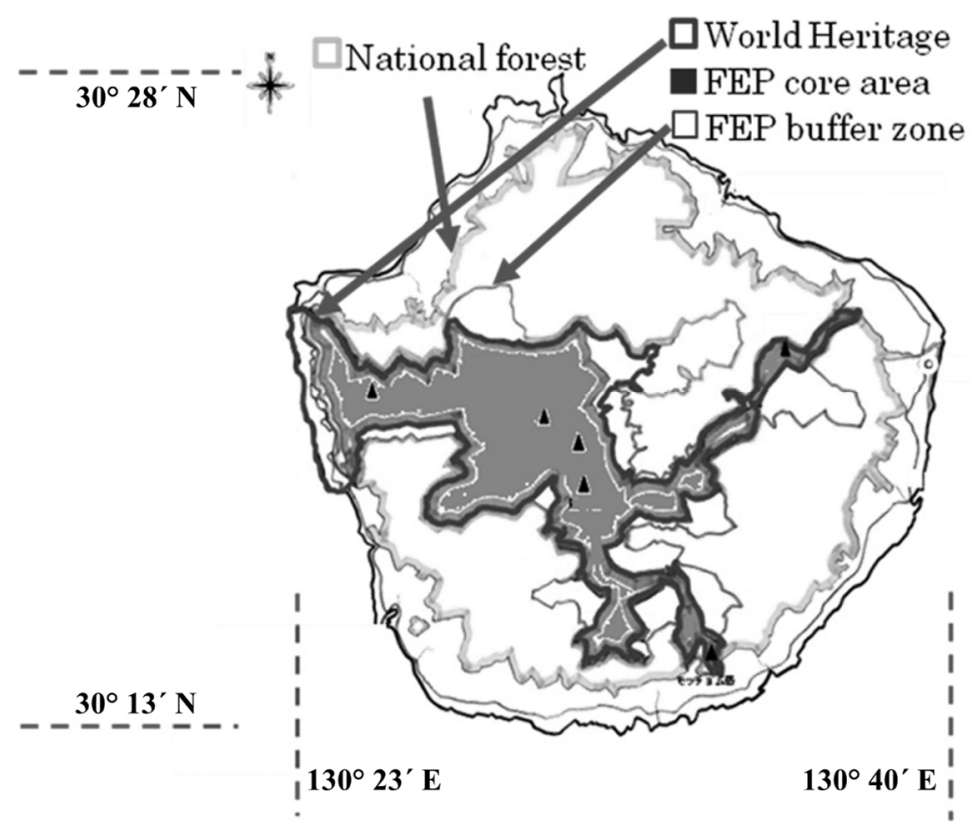

Figure 1. Yakushima Island showing the WHS and Forest Ecosystem Protected (FEP) area [38].

For the qualitative data, literature and media were analyzed, and interviews were held with people involved in decision-making processes or activities related to the natural environment of Yakushima. We analyzed scientific papers and Japanese newspapers to identify environmental issues in connection with tourism in scientific papers on Yakushima in Japanese and English. We did not include the large number of papers on Yakushima monkeys, as they mostly focus on monkey behavior and ecology (e.g., reference [47]). To cover the general media discussion, we analyzed one of Japan's leading newspapers, Asahi Shinbun, which is available as a database in institutions with a contract, like Japanese university libraries. After searching with the keywords "Yakushima" and "environment", we narrowed the selection down to articles that dealt directly with environmental issues on Yakushima, excluding those announcing events, mentioning Yakushima only by name or comparing NTB and WNHS sites.

The semi-structured interviews were conducted in two parts. The first part, focusing on impacts of tourism on the environment was conducted to provide information about the perception of stakeholders involved in the administration. The authors (I.B.A. and C.F.) held semi-structured interviews with Yakushima Environmental Culture Village Center, Yakushima Tourism Association, Yakushima World Heritage Conservation Center, and Yakushima Forest Conservation Center in 2015. The second part of the interview targets participants involved in activities related to nature of Yakushima. The author (R.U.) carried out semi-structured interviews in two different periods: 3-10 March 2017 and 8-28 February 2018. The interview targets were selected using purposive sampling and snowball sampling. The respondents included 26 tour guides (one of which is a hunter and three are farmers as well), 
three farmers, two hunters, a deer management committee member, an accommodation owner who used to work as an environmental activist, and a Non-profit Organization (NPO) worker. Twenty-one respondents were immigrants who were born outside of the island and 13 were islanders who were born in Yakushima. Analysis in this paper concentrates on their perceptions on environmental issues.

The quantitative data was analyzed using descriptive statistical analysis, and independent $t$-test. The descriptive statistical analysis was used to identify the profile of the stakeholders and to determine the means and standard deviation of each of the six tourism impact items. An independent $t$-test was employed to compare the difference in perceptions between the residents and tourism practitioners by analyzing the significant difference between their means. For the qualitative data, the interviews were transcribed and content analysis was used to examine what interviewees were discussing.

\section{Results}

\subsection{Review of Environmental Discussions on Yakushima over the Past Two Decades}

More than 40 mostly Japanese scientific publications concerning tourism and environmental issues on Yakushima can be counted since World Heritage registration. Most of them covered tourism industries, especially ecotour guides, analyzed tourist flows and behavior or simply described the current situation of ecotourism on the island. Baba mentioned as early as 1997 that some residents reported negative influences of tourism growth on their daily environment [40]. Several papers discussed the situation of the ecotour business as a positive example of a new local industry created through tourism $[48,49]$. At the time when tourist numbers reached their peak in 2007, Shibasaki et al. and Baba for the first time pointed out problems of overuse in the mountain areas and methods to address them [36,37]. Forbes mentioned control of the number of visitors concentrating around Jomonsugi and the disposal of sewage from huts and toilets in mountain areas as the two most persisting problems in Yakushima [35]. Okano and Matsuda emphasized that tourists are only interested in the main spots and not in the biodiversity of the island as a whole [39]. Shibasaki pointed out that there is a cycle of development that reinforces the negative effects on the environment around the popular trails [50]. To solve the problems of hikers using the forest as toilet or damaging vegetation along the trail and of congested roads and parking near the trailhead to Jomonsugi, Yakushima town created more toilets and boardwalks along the trail and introduced a shuttle bus service in combination with restrictions for private cars. This in turn led to an increase in hikers, thus putting more stress on the environment. Another tourism resource threatened by an increase in visitor numbers is the beaches where sea turtles nest in summer $[35,50]$.

Both Shibasaki and Forbes pointed to complicated management structures as an important reason for these problems [35,50]. As mentioned above, Yakushima is not only World Natural Heritage, but also designated as a National Park and a UNESCO Biosphere Reserve and Wilderness Area. As a result, a number of government agencies from the national to the local scale are involved in management but an overall concept is not present. Furthermore, both authors criticized managing agencies for prioritizing local economic interests over environmental protection. This can be exemplified from the ecotour guide industry, where attempts to create a guide registration system to control the quality of tour guide continued without success since 2006 [51], until finally an ordinance was introduced in 2016. The new system encourages guides to receive a qualification because several merits are assigned to qualified guides, but it does not restrict the activities of guides without qualification.

If we follow the reports on environmental issues in Yakushima in the Asahi newspaper, we can see that two main issues have appeared throughout the years, albeit from different perspectives (Table 1). One is the number and concentration of hikers to Jomonsugi and how to manage them, and the other is the problem of toilets in the mountain areas. 
Table 1. List of environmental topics on Yakushima in articles between 2009 and 2018.

\begin{tabular}{|c|c|c|c|c|}
\hline Year & No. of Articles & Articles Chosen & Issues & Management Policies \\
\hline 2009 & 54 & 2 & $\begin{array}{l}\text { Too many hikers to Jomonsugi cause } \\
\text { trampling damage } \\
\text { Too many tourists disturb sea turtles }\end{array}$ & \\
\hline \multirow{5}{*}{2010} & \multirow{5}{*}{65} & \multirow{5}{*}{4} & $\begin{array}{l}\text { Increase in tourists causing a burden } \\
\text { for the environment }\end{array}$ & $\begin{array}{l}\text { Support for introduction of } \\
\text { Electronic Vehicles }\end{array}$ \\
\hline & & & $\begin{array}{l}\text { Transport of toilet sewage from } \\
\text { mountain area }\end{array}$ & Promote disposable toilets to hikers \\
\hline & & & Increase in tourists to Jomonsugi & Introduction of traffic restrictions \\
\hline & & & Diversification of tourist activities & Start of village tours on local culture \\
\hline & & & Congestion at Jomonsugi & $\begin{array}{l}\text { Publish calendar with } \\
\text { congestion predictions }\end{array}$ \\
\hline \multirow[t]{3}{*}{2011} & \multirow[t]{3}{*}{45} & \multirow[t]{3}{*}{$10 * 1$} & Congestion at Jomonsugi & $\begin{array}{l}\text { Discussion on limitation of visitors } \\
\text { to Jomonsugi } \\
\text { Proposal dismissed in town council } \\
\text { for economic reasons } \\
\text { Issue in mayor election }\end{array}$ \\
\hline & & & $\begin{array}{l}\text { Cost of toilet disposal from } \\
\text { mountain area }\end{array}$ & Introduction of bio-toilet \\
\hline & & & $\begin{array}{l}\text { Congestion at Jomonsugi leads to } \\
\text { trampling damage }\end{array}$ & Suggestion: make guide compulsory \\
\hline 2012 & 48 & 3 & Issues of congestion, deer damage & $\begin{array}{l}\text { Restriction on smoking along } \\
\text { Jomonsugi trail } \\
\text { New monitor plan for Yakushima: } \\
\text { first change since WH registration } \\
\text { Success: more than } 100 \text { electric cars }\end{array}$ \\
\hline \multirow[t]{2}{*}{2013} & \multirow[t]{2}{*}{$79 * 2$} & \multirow[t]{2}{*}{2} & $\begin{array}{l}20 \text { years since designation: still } \\
\text { problems of congestion and toilets on } \\
\text { Jomonsugi trail }\end{array}$ & \\
\hline & & & & $\begin{array}{l}\text { Discussion on island tax to cover costs } \\
\text { for toilet disposal etc. }\end{array}$ \\
\hline 2014 & 55 & 1 & (Reflection: effects of WH registration) & \\
\hline \multirow{3}{*}{2015} & \multirow{3}{*}{$73 * 3$} & \multirow{3}{*}{4} & & $\begin{array}{l}\text { Discussion on donation system } \\
\text { for hikers }\end{array}$ \\
\hline & & & $\begin{array}{l}\text { Widening of access road to mountain } \\
\text { area threatens rare flower species } \\
\text { Report on environmental situation in } \\
\text { Scientific Committee: no. of hunted } \\
\text { deer, toilets }\end{array}$ & \\
\hline & & & & $\begin{array}{l}\text { Idea to use former mountain rail } \\
\text { for tourists }\end{array}$ \\
\hline \multirow[t]{3}{*}{2016} & \multirow[t]{3}{*}{56} & \multirow[t]{3}{*}{$10 * 4$} & Number of hikers decreasing & $\begin{array}{l}\text { New guide registration and } \\
\text { qualification system introduced } \\
\text { Suggestion: new hiking style should } \\
\text { be developed } \\
\text { Introduction of mountain } \\
\text { donation decided }\end{array}$ \\
\hline & & & $\begin{array}{l}\text { (Series on } 50 \text { years discovery of } \\
\text { Jomonsugi: history of preservation, } \\
\text { new ideas for better } \\
\text { hiking environment) }\end{array}$ & \\
\hline & & & $\begin{array}{l}\text { Problems at mountain huts: } \\
\text { garbage etc. }\end{array}$ & $\begin{array}{l}\text { Suggestion: install managers during } \\
\text { high season }\end{array}$ \\
\hline \multirow{4}{*}{2017} & \multirow{4}{*}{55} & \multirow{4}{*}{7} & $\begin{array}{l}\text { Concentration of hikers, toilet sewage } \\
\text { disposal, quality of mountain huts }\end{array}$ & $\begin{array}{l}\text { Discussion on management methods } \\
\text { for five years } \\
\text { Start of mountain donation system }\end{array}$ \\
\hline & & & $\begin{array}{l}\text { Water quality } \\
\text { Widening of access road to mountain } \\
\text { area threatens rare flower species }\end{array}$ & Investigation conducted \\
\hline & & & Increase in international visitors & $\begin{array}{l}\text { Electric vehicle car rental started } \\
\text { Necessary: information, } \\
\text { safety measures }\end{array}$ \\
\hline & & & Number of hikers and accidents & \\
\hline 2018 & 47 & 5 & $\begin{array}{l}\text { NPO that supported conservation of } \\
\text { sea turtles gives up activities } \\
\text { NPO finds successor for activities } \\
\text { (Residents meeting) }\end{array}$ & $\begin{array}{l}\text { Discussion on rules for sea turtle } \\
\text { observation tours }\end{array}$ \\
\hline
\end{tabular}

Reason for high number of articles: * 1 : Discussion on limitation of visitors to Jomonsugi. ${ }^{*} 2$ : 20 years WH registration.

*3: Volcanic eruption on smaller island that is part of Yakushima Town. *4: Discussion on mountain donation. 
Due to its high degree of name recognition, Jomonsugi attracts not only the majority of hikers but also of media attention. The consistent issues in the media are how to manage tourist numbers and concentration, and how to create funds for environmental management. However, after 2016, due to the decrease in visitors, discussion shifts to better management of the tourism infrastructure in the mountains.

\subsection{Impacts of Tourism on the Environment as Perceived by Residents and Tourism Practitioners}

The profile of the 197 residents sampled revealed that $60 \%$ of the respondents were male and $39 \%$ of them were female. Of all the respondents, $76 \%$ were more than 50 years old, $63 \%$ were employed at the time of the study, while $26 \%$ were unemployed and others were retired and/or were working part-time. The majority of the respondents were islanders $(62 \%)$ and the remaining $38 \%$ were migrants. Based on length of residency, $25 \%$ of the respondents have lived on the island since birth, $47 \%$ were I-turns (migrants from outside the island) while the remaining were U-turns (islanders who returned to Yakushima after spending time outside). Of the 114 questionnaires completed by the tourism practitioners, male and female respondents had an equal representation of $50 \% ; 40 \%$ of the respondents were 40 years old and below. With regard to the position of the respondents at the facility, $43 \%$ were business owners, $19 \%$ were family members of the owner, $14 \%$ were managers, $9 \%$ were the managers' family member and the remaining $15 \%$ were staff of the facility. Of all the respondents, 57\% were migrants. Regarding their length of residency, only $14 \%$ of the respondents have lived on the island since birth, $57 \%$ had I-turn patterns and the remaining had U-turn patterns.

Perceptions of both residents and tourism practitioners about environmental impacts of tourism were measured using 6-items on a five point Likert scale. Descriptive statistics revealed that both stakeholder groups rated highest on an increase of trash in the community and lowest on overcrowding in the community. This indicates a similarity in the direction of their perceptions. As seen in Figure 2, increase in trash due to tourism had the highest rating, with about $60 \%$ of both groups scoring higher than 3-point. The majority of the respondents do not agree that tourism has contributed to a greater protection of the natural environment. The degree of agreement is lowest for the statement that tourism causes overcrowding in the community, with more than $90 \%$ of both groups scoring 3 points and below.

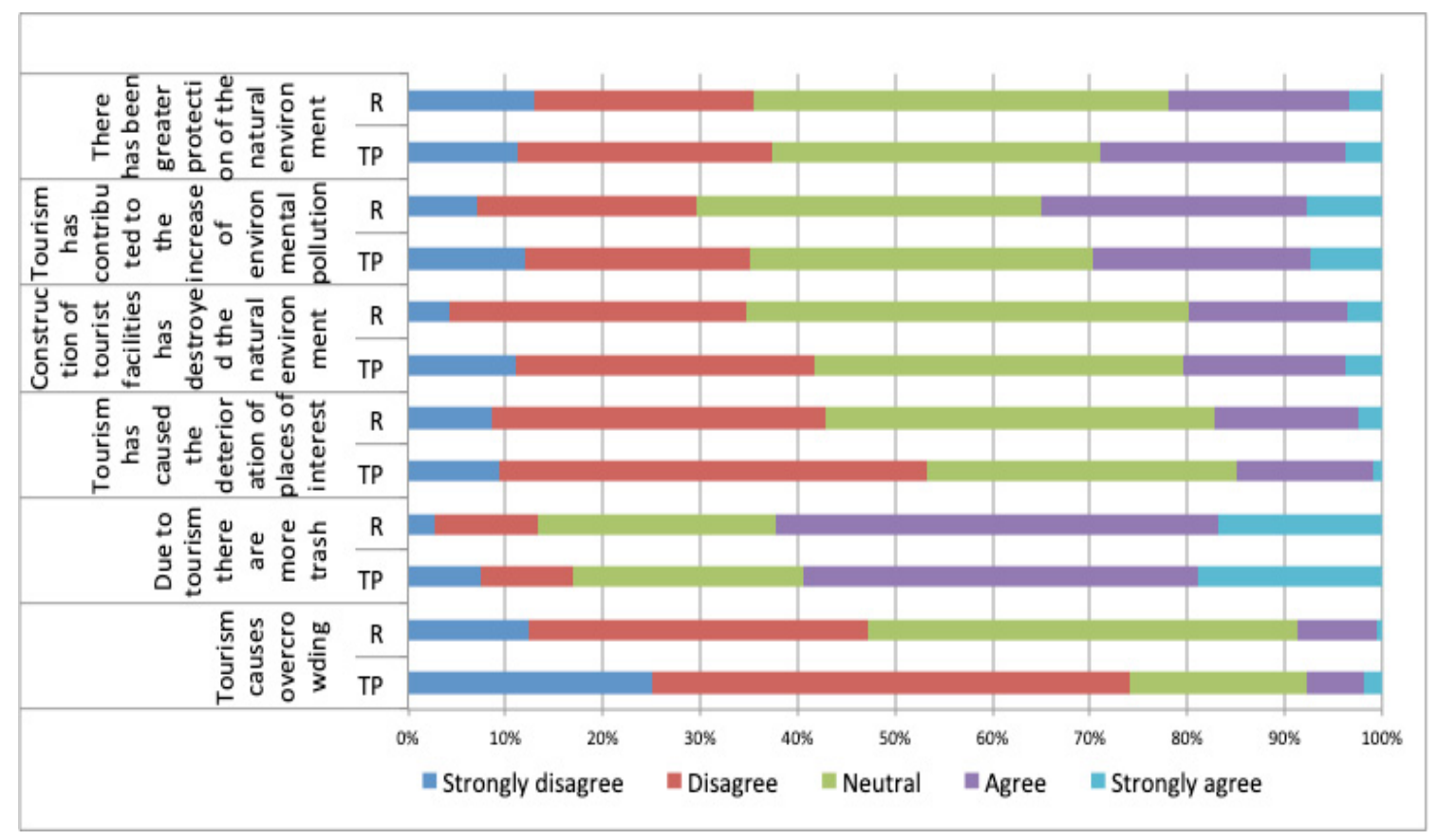

Figure 2. Ratings of stakeholders' perception of tourism impacts. Note: $\mathrm{R}=$ Residents, $\mathrm{TP}=$ Tourism Practitioners. 
To examine the differences in perceptions about tourism impacts between the two study groups, $t$-tests were conducted. Table 2 shows that both residents and tourism practitioners have similar perceptions about the impact of tourism, thus t-tests did not reveal any statistically significant differences between the responses of the two groups. The result reveals that the ratings of both groups and the impact of tourism on overcrowding in the community were the lowest in both groups (residents $=2.185$, tourism practitioners $=1.955$ ), suggesting that both groups do not believe that tourism in Yakushima is causing overcrowding in the communities. The increase of trash in the community had the highest ratings for both stakeholder groups.

Table 2. Test of significance between residents and tourism practitioners ( $t$-Test).

\begin{tabular}{|c|c|c|c|c|c|c|}
\hline \multirow{2}{*}{ Environmental Impacts of Tourism } & \multicolumn{2}{|c|}{$\mathbf{R}$} & \multicolumn{2}{|c|}{ TP } & \multirow{2}{*}{$t$} & \multirow{2}{*}{ Sig. } \\
\hline & Mean & SD & Mean & SD & & \\
\hline $\begin{array}{l}\text { There has been greater protection of the natural } \\
\text { environment due to tourism }\end{array}$ & 2.581 & 1.1976 & 2.739 & 1.1577 & -1.116 & 0.265 \\
\hline $\begin{array}{l}\text { Tourism has contributed to the increase of } \\
\text { environmental pollution }\end{array}$ & 2.825 & 1.2933 & 2.820 & 1.1924 & 0.035 & 0.972 \\
\hline $\begin{array}{l}\text { The construction of hotels and other tourist facilities } \\
\text { has destroyed the natural environment of Yakushima }\end{array}$ & 2.582 & 1.1706 & 2.640 & 1.0770 & -0.426 & 0.671 \\
\hline $\begin{array}{l}\text { Tourism has caused the deterioration of places of } \\
\text { historical and cultural interest }\end{array}$ & 2.362 & 1.2219 & 2.441 & .9880 & -0.610 & 0.542 \\
\hline Due to tourism there are more trash in the community & 3.557 & 1.2648 & 3.409 & 1.2943 & 0.963 & 0.336 \\
\hline Tourism causes overcrowding in the community & 2.185 & 1.1397 & 1.955 & 1.0344 & 1.780 & 0.076 \\
\hline
\end{tabular}

Note: $\mathrm{R}=$ Residents, $\mathrm{TP}$ = Tourism Practitioners, the higher the mean, the higher the level of agreement.

\subsection{Perceptions of Administration about Environmental Issues Connected to Tourism}

The results of the interviews are presented in Table 3. The four organizations interviewed reiterated that the underlying environmental impacts of tourism in Yakushima were, pressure on mountain trails to Jomonsugi, vegetation trampling, and waste management including sewage.

Table 3. Tourism related environmental issues in Yakushima.

\begin{tabular}{|c|c|c|c|}
\hline $\begin{array}{l}\text { Environmental Issues } \\
\text { Connected to Tourism }\end{array}$ & Causes of the Issues & $\begin{array}{l}\text { Interviewed Organization } \\
\text { Stating the Issues }\end{array}$ & Effects \\
\hline \multirow{2}{*}{$\begin{array}{l}\text { Pressure on mountain trails to } \\
\text { Jomonsugi resulting in damage of } \\
\text { the trails }\end{array}$} & \multirow{2}{*}{ Congestion along Jomonsugi trail } & $\begin{array}{l}\text { Yakushima Environmental } \\
\text { Culture Village Center }\end{array}$ & $\begin{array}{l}\text { Damage to the forest } \\
\text { and equipment }\end{array}$ \\
\hline & & Yakushima Tourism Association & $\begin{array}{l}\text { Constant repair of trails } \\
\text { is required }\end{array}$ \\
\hline Vegetation trampling & People walk on the vegetation & $\begin{array}{l}\text { Yakushima World Heritage } \\
\text { Conservation Center }\end{array}$ & $\begin{array}{l}\text { Threat of some rare species } \\
\text { becoming endangered }\end{array}$ \\
\hline Damages to soil structure & $\begin{array}{l}\text { Use of walking } \\
\text { sticks/hiking poles }\end{array}$ & $\begin{array}{l}\text { Yakushima World Heritage } \\
\text { Conservation Center }\end{array}$ & \\
\hline \multirow{2}{*}{$\begin{array}{l}\text { Human waste } \\
\text { (sewage) management }\end{array}$} & $\begin{array}{l}\text { Treatment of sewage to prevent } \\
\text { contamination of rivers }\end{array}$ & Yakushima Tourism Association & \multirow[t]{2}{*}{$\begin{array}{l}\text { Carried down the mountains } \\
\text { for proper disposal } \\
\text { Strenuous and expensive }\end{array}$} \\
\hline & $\begin{array}{l}\text { Wastes flow into nearby rivers } \\
\text { during the tourism season }\end{array}$ & Town councillor & \\
\hline $\begin{array}{l}\text { Increase of garbage in } \\
\text { the mountains }\end{array}$ & Increase in number of tourists & $\begin{array}{l}\text { Yakushima World Heritage } \\
\text { Conservation Center }\end{array}$ & \\
\hline $\begin{array}{l}\text { Problem of maintaining the } \\
\text { natural environment and } \\
\text { increase in tourist }\end{array}$ & Increase in tourists & $\begin{array}{l}\text { Yakushima Environmental } \\
\text { Culture Village Center }\end{array}$ & $\begin{array}{l}\text { Efforts are being made to } \\
\text { balance both tourism and } \\
\text { environmental management }\end{array}$ \\
\hline
\end{tabular}


Although the residents and tourism practitioners agreed that tourism does not really cause overcrowding in the communities, the interviews and participant observation revealed that overcrowding occurs in the mountain and forest areas. Consequently, most of the negative effects of overcrowding were experienced in the forest regions, resulting in trampling on vegetation and destruction of mountain trails. The interviewees at the four organizations confirmed that the large number of tourists along the mountain trails to Jomonsugi imposed pressure on, and damage to the trails. Another problem associated with tourism in Yakushima was that many people walk outside the trail, hence trampling on the vegetation and threatening some rare species with the possibility of becoming endangered. Also, people using walking sticks/hiking poles damaged the soil structure.

The finding of the study reveals that the numbers of toilets in the mountains are not enough to match up with the number of tourists hiking up the mountains. Apart from the insufficient number of toilets in the mountains, there is also the problem of sewage treatment without contaminating the rivers and vegetation. Since the nature of Yakushima is important for its existence as a WNHS, sewage is not allowed to discharge into the sea but instead is collected and carried down the mountains by the ecotour guides during the off season for proper disposal. This is usually a strenuous process and requires a lot of funds. Despite efforts made in preventing sewage from polluting the rivers, it was discovered that wastes flow into nearby rivers during the tourism season due to the overcapacity of the tourists. An increase of garbage in the mountains as a result of increase in the number of tourists was only mentioned by one of the organizations interviewed.

The results show that striking a balance between the economic benefits of tourism and its impacts on Yakushima's environment has become a major challenge for the organizations. However, efforts are being to solve the problem of balancing the economic benefits of tourism and waste management as the future task of this organization.

In 2017, the Nature Regeneration Planning Officer on Yakushima, who represents the Kyushu Regional Environment Office of the Ministry of the Environment Japan, sent a report on the state of conservation of Yakushima to the International Union for Conservation of Nature This brief report offers a fairly recent overview of how the official management authority on the island describes its environmental problems. The report mentions management of Yaku sika deer and management of tourists as the most important issues. The increase in deer continues to pose risks to vegetation, for example a decrease of endangered plant species, a decline of forest floor vegetation, and soil erosion. On the other hand, the stabilization of tourist numbers on a lower level since 2008 has reduced the damage caused by the high number of visitors such as crowding or trampling of vegetation. Introduction of a monitor plan (2011), establishment of a Review Committee for the Utilization of Mountainous Part of Yakushima World Natural Heritage and National Park (2016) and the collection of Word Natural Heritage Site Yakushima's Mountain Environmental Conservation Donations since 2017 are cited as efficient measures to control negative impacts on the environment (Nature Regeneration Planning Officer on Yakushima 2017: Conservation State of Yakushima).

\subsection{Perceptions of Environmental Issues Connected to Deer Management}

We observed contrasting views between Yakushima's deer management officials and tour guides on their perceptions toward the deer. In particular, their perspectives on whether or not the deer population is growing are polar opposites: the management officials claim it is, whereas the tour guides experience a different trend in the mountain habitat.

The deer management officials have a conflicting relationship with the deer in Yakushima Island. The interviewee at Yakushima Forest Conservation Center claimed the center is faced with the problems of managing the increase in deer population, with on-going studies to determine the number of deer that can be removed in order to create a better balance. The conflict of interests is that a high deer population density $\left(96.7\right.$ deer $/ \mathrm{km}^{2}$ ) causes forest recession, which would threaten Yakushima's registration as a UNESCO WNHS. Thus, the deer population control is placed at utmost priority among 
the Yakushima's environmental management officials. To reduce the deer population, culling has been implemented. The annual goal of culling 5,000 deer was encouraged by providing subsidies to hunters.

While the deer management authority's narrative emphasized the overpopulation of deer, a majority of tour guides reported the sudden disappearance of deer from the forests. Many of them seemed confused about what is happening and why the deer they used to see on multiple occasions during the tour are now gone. For example, a male tour guide (in 2017) stated "About two years ago, a lot of deer died. I don't know the reason. Ministry of Environment officers said due to the long-lasting rain, the deer lost their physical strength and died. But I don't know the real cause. Perhaps, someone poisoned the deer. That same year, Kuchinoerabu Island had a volcanic eruption. At the end of that year to the following year, many deer died, an insane number of the deer. I used to see 30 to 40 deer going to Jomonsugi and coming back from there. Now, I only see two or three deer".

While the management officials see the increased deer population as a negative influence on tourism, tour guides find them important for tourists' experiences. Many reported that encountering the deer could be an added value for their clients. Therefore, the deer's disappearance can influence the tourist experience in Yakushima negatively. For example, a female tour guide (in 2017) stated "For tourism, the presence of the deer on the mountain is beneficial. Yesterday, my client happened to spot a deer in the distance. Probably the deer was with a foe. Before this was normal. If you go hiking, you would definitely see at least one deer. Some people would see the deer more than ten times. There were so many deer that the tour itself got distracted by them. This was normal two years ago, but now it rarely happens"' (Tour guide B, Female, 2017).

In addition to the contrasting views on the deer population status, a further issue emerged concerning the approach that the management officials have implemented to decrease the deer population. One tour guide said that it is unclear for "whom" we are culling the deer.

\section{Discussion}

This study demonstrated that issues discussed in scientific papers are mainly on tourism overuse in the mountain areas and the sea turtle beaches in Yakushima. They identify complicated management structures and a lack of tourism industry control as the main culprits for this situation. However, in the media, especially Asahi newspaper-considered to be Japan's most critical newspaper-most of the discussions are focused on management of tourist numbers and funds generation for environmental management, while problems mentioned in scientific papers like the overall management structure or biodiversity as a whole are left untouched.

The results of the study indicated that there is no statistically significant difference between the perceptions of residents and practitioners about environmental impacts of tourism. Although perceptions between residents and entrepreneur have been found to vary [10], the finding of this study is similar to those of reference [26], and reference [52] where no statistically significant difference existed between the perceptions of residents and entrepreneurs about tourism impacts. All stakeholder expressed concern over the negative impact of tourism on the environment. Both residents and tourism practitioners highly agreed that tourism has contributed to the increase of trash in the community. Although this had the highest rating within both groups, the management officials interviewed rarely mentioned this. Only the interviewee at the Yakushima World Heritage Conservation Center made mention of an increase in garbage due to the increase in tourists. However, the management officials placed more emphasis on other negative environmental impacts such as trampling and sewage problem. The similarity in the perceptions of the stakeholder groups and emphasis in literature about the negative impacts of tourism on the environment reveals that this has been a recurrent theme in Yakushima. It is evident that if not properly managed, tourism poses a threat to the environment of the island, which is the basis for its inscription on the WNHS and its importance as a NBT destination.

The results of the study indicated that the most significant negative environmental impacts of tourism are pressure on mountain trails to Jomonsugi, vegetation trampling and waste management. These negative impacts of tourism on the nature of Yakushima have also been reported in prior 
studies [35-37]. Although both residents and tourism practitioners agreed that tourism does not really cause overcrowding in the communities, the interviews with the various organizations and participant observation revealed that overcrowding occurs in the mountain and forest areas. Consequently, most of the negative effects of overcrowding are felt in the forest regions, resulting in trampling on vegetation and destruction of mountain trails. This is a common occurrence in most NBT destinations. It has been noted that when the level of tourist use is more than what the environment of a destination can handle, tourism can negatively impact the environment and eventually destroy the environmental resources on which tourism depends if it is not managed [53]. Some of the discovered adverse effects of tourism on the environments are pressure on the area, soil erosion, discharges into the sea, and increased pressure on endangered species [54]. Asadzadeh and Mousavi also reported that tourism has led to the destruction of the natural environment through hiking [55]. Sunlu noted that a high number of tourists using a particular trail for a long period of time could lead to vegetation and soil trampling [54]. Tourism has also been found to result in noise pollution, litter, erosion and depletion of natural resources [56-58].

Furthermore, the study shows that although efforts are taken by management to prevent sewage discharge into water bodies, some stakeholders noted that wastes still flow into nearby rivers during the tourism season. Tourism has been reported as a source of water pollution in some destinations [53,59]. Grössling et al. noted that the tourism industry consumes and pollutes water resources [60]. In Bhimtal, India, tourism was discovered to have adverse impacts on the environment in terms of water pollution [61]. Also, some Yakushima residents fear that the rivers are being polluted by deer carcasses. Hence, tourism not properly managed results in damage to the natural environment and wildlife, pollution to rivers and loss of natural landscape among others effects [62-65]. Compared to this wide array of issues, discussion in the media and by administrative authorities on Yakushima very narrowly focuses on trampling and human waste in mountain areas. Residents and tourism practitioners on the other hand mainly notice an increase in garbage in communities.

The majority of respondents addressed in the questionnaire do not perceive tourism as a helpful tool in the protection of the natural environment of Yakushima. This is contrary to previous studies, which argue that tourism contributes to environmental protection and conservation $[54,66,67]$. In some studies, tourism has been noted to lead to protection of both the natural and cultural environment $[65,68]$. Andereck et al. noted that tourism contributes to the improvement of environmental resources because it often demands the preservation of the natural heritage and improvement of public facilities [57]. Tourism in NPs has also been noted to contribute to the conservation of nature [66,67]. According to Zhao and $\mathrm{Li}$, increased environmental awareness through tourism positively influences the environment [69]. However, due to the aforementioned negative impacts of tourism on the environment of Yakushima, the majority of the respondents do not feel that tourism contributes to environmental protection of the island.

Apart from the negative impact of tourism on the environment of Yakushima, we also found that overabundance of deer poses a threat to the vegetation of the island. The deer population increase has been a critical issue throughout Japan [70]. Especially in NPs, conflicts emerged between humans who value vegetation of the parks and the deer that utilize it as a food resource. Over the years, the Yakushima deer management has always emphasized the increase in deer population. In contrast, the interviews with tour guides suggest that at least the visible deer population is not on the increase as thought. It can be argued that the perceptions of the tour guides about deer population are formed based on their direct encounter with the deer on a daily basis.

Since it was stated during the interview at Yakushima Forest Conservation Center that there is on-going research to determine the deer population on the island, it is necessary to incorporate the opinions of tour guides to determine the current deer situation and make necessary amendments to deer hunting. The connection of the deer issue to tourism turned out to be very complex, as overabundance of deer endanger parts of the vegetation tourists come to enjoy while at the same time deer are an important part of the tourists experience on hiking tours and have also been branded as 
a local food product. Culling the deer under such a circumstance could generate an ethical debate as to whether it is morally right to hunt the deer to protect Yakushima's precious vegetations. The fact that the majority of culled deer are only discarded in the mountains raises questions about our moral standing. This is an important ethical debate that needs to be investigated further but it is beyond the scope of this research. In our future research, we intend to emphasize the ethics in wildlife management at NBT with a particular focus on the vernacular species such as deer. Still, this study has shed light on an important discussion dimension on managing NBT destinations.

\section{Conclusions}

This study investigated multiple stakeholder groups' perceptions of the environmental issues in Yakushima Island. By reviewing the issues the residents in Yakushima experienced over time, we examined perceptions in a more holistic manner. Results indicated that the underlying environmental issues in Yakushima result from an increase in the number of tourists visiting the forest areas, and a perceived overabundance of deer. Consequently, the increase in the tourist population to the forest areas led to congestion along the access roads and trail to Jomonsugi, vegetation trampling, and general waste management. However, the discussion on actual environmental issues in national media is very narrowly focused on trampling and overcrowding along the trail itself and human sewage disposal. The results also showed that residents and tourism practitioners both agreed that an increase of trash in the community and environmental pollution were the most significant impacts of tourism on the environment. Likewise, an increase in deer population resulted in over-grazing pressure on vegetation of the island. Both issues have been discussed over a prolonged period of time. With a decrease in tourists since 2008, attention has shifted to the latter issue.

The study contributes to the discussion on the use of CPRs in NBT destinations in two important points. First, the results of the study demonstrated that environmental issues at a NBT destination are not only limited to tourism related issues, but also occur due to competition between other users of CPRs. In the case of Yakushima, deer is seen as a user and threat to the natural environment of the NBT destination while at the same time, it is an important part of the tourism experience and therefore itself part of the CPR. The second important finding of this study is that there is a difference in perceptions of tour guides about overabundance of deer and how management authorities and literature represent the issues. Over the years, management authorities and literature have always emphasized the increase in the deer population, though we found that most tour guides reported the opposite. Hence, there is a need for greater communication between the management authorities and tour guides, as well as other stakeholder groups. The environmental management authorities may not be aware of the condition of the deer population and the actual decrease in sighting experienced by tour guides that go to the mountains frequently. In addition to the research carried out by the management authorities, communicating with the other stakeholder groups can further help in better understanding the perceptions and realities of deer living in the mountain regions. This can consequently help in taking the appropriate measure in controlling the deer population and overall environmental management.

Author Contributions: Conceptualization, I.B.A., R.U. and C.F.; Methodology, I.B.A., R.U. and C.F.; Software, I.B.A.; Validation, I.B.A., R.U. and C.F.; Formal Analysis, I.B.A., R.U.; Investigation, I.B.A., R.U. and C.F.; Data Curation, I.B.A., R.U. and C.F.; Writing-Original Draft Preparation, I.B.A.; R.U. and C.F.; Writing-Review \& Editing, I.B.A., R.U. and C.F.; Visualization, I.B.A., R.U. and C.F.; Supervision, C.F.

Funding: Fieldwork in 2015 by I.B.A. and C.F. was supported through the Hiroshima University TAOYAKA Program for creating a flexible, enduring, peaceful society, funded by the Program for Leading Graduate Schools, Ministry of Education, Culture, Sports, Science and Technology, by the 21st Century Science Projects of the Graduate School of Integrated Arts and Sciences (Hiroshima University) and by the Japan Society for the Promotion of Science Grant-in-Aid for Scientific Research Project JP26360065 (C.F.). Also, the fieldwork conducted by Rie Usui was supported through the Hiroshima University TAOYAKA Program for creating a flexible, enduring, peaceful society, funded by the Program for Leading Graduate Schools, Ministry of Education, Culture, Sports, Science and Technology.

Acknowledgments: This research was conducted at Hiroshima University Graduate School of Integrated Arts and Sciences. Ifeoluwa Bolanle Adewumi has since graduated from this school. 
Conflicts of Interest: The authors declare no conflict of interest.

\section{References}

1. Newsome, D.; Moore, S.; Dowling, R.K. Natural Area Tourism: Ecology, Impacts and Management; Channel View Publications: Clevedon, UK, 2002.

2. Kuenzi, C.; McNeely, J. Nature-Based Tourism. In Global Risk Governance: Concept and Practice Using the IRGC Framework; Renn, O., Walker, K., Eds.; Springer: Berlin/Heidelberg, Germany, 2008; pp. 155-178.

3. Thapa, B.; Lee, J. Visitor experience in Kafue National Park, Zambia. J. Ecotour. 2017, 16, 112-130. [CrossRef]

4. Choe, H.; Yun, S.-J. Revisiting the Concept of Common Pool Resources: Beyond Ostrom. Dev. Soc. 2017, 46, 113-129.

5. Ostrom, E.; Burger, J.; Field, C.B.; Norgaard, R.B.; Policansky, D. Revisiting the commons: Local lessons, global challenges. Science 1999, 284, 278-282. [CrossRef] [PubMed]

6. Huang, D.S.; Huang, Y.Y.Common-Pool Resources, ecotourism and sustainable development. Taipei Econ. Inq. 2017, 53, 87-128.

7. Van der Duim, R.; Caalders, J. Biodiversity and tourism: Impacts and interventions. Ann. Tour. Res. 2002, 29, 743-761. [CrossRef]

8. Hakim, L. Managing biodiversity for a competitive ecotourism industry in tropical developing countries: New opportunities in biological fields. AIP Conf. Proc. 2017, 1908. [CrossRef]

9. Janér, A.; Bezerra, N.P.; Ozorio, R.Z. Mamiraua: Community-Based Ecotourism in a Sustainable Development Reserve in the Amazon Basin. In Sustainable Hospitality and Tourism as Motors for Development; Sloan, P., Simons-Kaufmann, C., Legrand, W., Eds.; Routledge: New York, NY, USA, 2012; pp. 93-113.

10. Jaffe, E. Ecotourism can harm the environment. In What is the Impact of Tourism? Espejo, R., Ed.; Greenhaven Press: Farmington Hills, Michigan, 2009.

11. English, B.J. Is Ecotourism Just Another Story of Paradise Lost? Tama Univ. Dep. Bull. 2017, 9, 1-12. Available online: http://id.nii.ac.jp/1361/00000881/ (accessed on 16 July 2019).

12. Nackoney, J.; Molinario, G.; Potapov, P.; Turubanova, S.; Hansen, M.C.; Furuichi, T. Impacts of civil conflict on primary forest habitat in northern Democratic Republic of the Congo, 1990-2010. Biol. Conserv. 2014, 170, 321-328. [CrossRef]

13. Matar, D.; Anthony, B.P. Application of modified threat reduction assessments in Lebanon. Conserv. Biol. 2010, 24, 1174-1181. [CrossRef]

14. FAO. Sustainable Wildlife Management and Human-Wildlife Conflict; No 4 CPW Factsheet; FAO: Rome, Italy, 2015.

15. Gill, R.M.A.; Beardall, V. The impact of deer on woodlands: The effects of browsing and seed dispersal on vegetation structure and composition. Forestry 2001, 74, 209-218. [CrossRef]

16. Habeck, C.W.; Schultz, A.K. Community-level impacts of white-tailed deer on understorey plants in North American forests: A meta-analysis. AoB Plants 2015, 7, plv119. [CrossRef] [PubMed]

17. Asnani, K.M.; Klips, R.A.; Curtis, P.S. Regeneration of woodland vegetation after deer browsing in Sharon Woods Metro Park, Franklin County, Ohio. Ohio J. Sci. 2006, 106, 86-92.

18. Yamada, H.; Takatsuki, S. Effects of deer grazing on vegetation and ground-dwelling insects in a Larch Forest in Okutama, Western Tokyo. Int. J. For. Res. 2015, 2015, 1-9. [CrossRef]

19. Keith, D.; Pellow, B.J. Effects of Javan rusa deer (Cervus timorensis) on native plant species in the Jibbon-Bundeena Area, Royal National Park, New South Wales. Linn. Soc. N. S. Wales 2005, 126, 99-110.

20. Jim, C.Y.; Xu, S.S. Stifled stakeholders and subdued participation: Interpreting local responses toward Shimentai Nature Reserve in South China. Environ. Manag. 2002, 30, 327-341. [CrossRef] [PubMed]

21. Rao, M.; Rabinowitz, A.; Khaing, S.T. Status review of the protected-area system in Myanmar, with recommendations for conservation planning. Conserv. Biol. 2002, 16, 360-368. [CrossRef]

22. Xu, J.; Chen, L.; Lu, Y.; Fu, B. Local people's perceptions as decision support for protected area management in Wolong Biosphere Reserve, China. J. Environ. Manag. 2006, 78, 362-372. [CrossRef] [PubMed]

23. Aas, C.; Ladkin, A.; Fletcher, J. Stakeholder collaborations and heritage management. Ann. Tour. Res. 2005, 32, 28-48. [CrossRef]

24. Byrd, E.T.; Bosley, H.E.; Dronberger, M.G. Comparisons of stakeholder perceptions of tourism impacts in rural eastern North Carolina. Tour. Manag. 2009, 30, 693-703. [CrossRef] 
25. Liu, J.; Ma, Y. The perceptual differences among stakeholders in the tourism supply of Xi'an City, China. Sustainability 2017, 9, 214. [CrossRef]

26. Andriotis, K. Community groups' perceptions of and preferences for tourism development: Evidence from Crete. J. Hosp. Tour. Res. 2005, 29, 67-90. [CrossRef]

27. Lankford, S.V. Attitudes and perceptions toward tourism and rural regional development. J. Travel Res. 1994, 32, 35-43. [CrossRef]

28. Hardy, A.L.; Beeton, R.J.S. Sustainable tourism or maintainable tourism: Managing resources for more than average outcomes. J. Sustain. Tour. 2001, 9, 168-192. [CrossRef]

29. Hsu, C.H.C.; Huang, S.S. Effect of travel motivation, past experience, perceived constraint, and attitude on revisit intention. J. Travel Res. 2009, 48, 29-44. [CrossRef]

30. Tosun, C.; Dedeoglu, B.B.; Fyall, A. Destination service quality, affective image and revisit intention: The moderating role of past experience. J. Dest. Mark. Manag. 2015, 4, 222-234. [CrossRef]

31. Livina, A.; Reddy, M. Nature Park as a resource for Nature-Based Tourism. Environ. Technol. Resour. 2017, I, 179-183. [CrossRef]

32. Jones, T.E. Nature-based tourism in a Japanese national park: A case study of Kamikochi. Bull. Tokyo Univ. For. 2009, 121, 87-116.

33. Jones, T. A life cycle analysis of nature-based tourism policy in Japan. Contemp. Jpn. 2012, 24, $179-211$. [CrossRef]

34. Havens, T. Parkscapes: Green Spaces in Modern Japan; University of Hawaii Pres: Honolulu, HI, USA, 2011.

35. Forbes, G. Yakushima: Balancing long-term environmental sustainability and economic opportunity. Kagoshima Immacul. Heart Coll. Res. Bull. 2012, 42, 35-49.

36. Shibasaki, S.; Hikita, K.; Yoshida, Y.; Nagata, N. The influence of World Natural Heritage Registration on the management system of regional resources. For. Econ. 2006, 59, 1-16.

37. Baba, H. Local residents perception on forest recreation from the example of Yakushima. J. For. Econ. 2007, $43,51-57$.

38. Matsuda, H.; Yumoto, T.; Okano, T.; Tetsuka, T.; Fujimaki, A.; Shioya, K. An extension plan of Yakushima Biosphere Reserve as a case study of consensus building of islanders. J. Ecol. Environ. 2015, 38, 241-247. [CrossRef]

39. Okano, T.; Matsuda, H. Bio-cultural diversity of Yakushima Island: Mountains, beaches, and sea. J. Mar. Isl. Cult. 2013, 2, 69-77. [CrossRef]

40. Baba, Y. The community residents' perceptions toward forest recreation: Yakushima Island as a case study. J. For. Econ. 1997, 43, 51-57.

41. Shibasaki, S.; Shoji, Y.; Tsuge, T.; Tsuchiya, T.; Nagata, N. The possibility of community participation in world heritage management: Exploring residents' perceptions of Yakushima Island in Kagoshima. Chikyū Kankyō 2008, 13, 71-80.

42. Uebayashi, Y. The current situation and challenges of tourism at Yakushima Island: Based on the resident's perception. Ryūkoku Daigaku Daigakuin Keizai Kenkyū 2011, 11, 29-30.

43. Baba, Y. The current situation of forest recreation in the government-owned land: The opinions of Yakusugi Land users. J. For. Econ. 1995, 127, 77-82.

44. Fukami, S.; Niki, K. The environmental conservation consciousness of visitors to Yakushima, Kagoshima Prefecture, Japan. Chiiki Kankyō Kenkyū 2012, 4, 29-41.

45. Adewumi, I.B.; Funck, C. Ecotourism in Yakushima: Perception of the People Involved in Tourism Business. Geogr. Sci. 2016, 71, 185-205. [CrossRef]

46. Hidayat, H. Yakushima-Japan: Sustainable Forest Management. In Sustainable Plantation Forestry: Problems, Challenges and Solutions; Springer: Berlin/Heidelberg, Germany, 2018.

47. Miyata, A.; Yoshihiro, S.; Takahata, Y.; Manda, M.; Furuichi, T.; Kurihara, Y.; Hayaishi, S.; Hanya, G. Changes of abundance of Japanese macaques in Yakushima over the past 20 years. Primate Res. 2017, 33, 1-8. [CrossRef]

48. Hirata, K. A new economic use of forest resources and the persons in charge: From the example of ecotour guides in Yakushima. J. For. Econ. 2001, 47, 35-40.

49. Tajima, Y. Ecotourism in Yaku-Island, Kagoshima Prefecture. Kagoshima Daigaku Kyoikugakubu Kenkyukiyo 2004, 55, 31-47. 
50. Shibasaki, S. Economic analysis of the ecotourism industries in Yakushima Island. Bull. Natl. Mus. Jpn. Hist. 2015, 93, 49-73.

51. Kanetaka, F.; Funck, C. The development of the tourism industry in Yakushima and its spatial characteristics. Stud. Environ. Sci. 2011, 6, 65-82.

52. Kavallinis, I.; Pizam, A. The environmental impact of tourism: Whose responsibility is it anyway? The case study of Mykonos. J. Travel Res. 1994, 33, 26-32. [CrossRef]

53. Dokulil, M.T. Environmental Impacts of Tourism on Lakes. In Eutrophication: Causes, Consequences and Control; Ansari, A.A., Gill, S.S., Eds.; Springer: Dordrecht, The Netherlands, 2014.

54. Sunlu, U. Environmental impacts of tourism. In Local Resources and Global Trades: Environments and Agriculture in the Mediterranean Region; Camarda, D., Grassini, L., Eds.; CIHEAM: Bari, Italy, 2003; pp. 263-270.

55. Asadzadeh, A.; Mousavi, M.S.S. The Role of Tourism on the Environment and Its Governing Law. Electron. J. Biol. 2017, 13, 152-158.

56. Ko, D.W.; Stewart, W. A structural equation model of residents attitudes for tourism development. Tour. Manag. 2002, 23, 521-530. [CrossRef]

57. Andereck, K.; Valentine, K.; Knopf, R.C.; Vogt, C.A. Residents' perceptions of community tourism impacts. Ann. Tour. Res. 2005, 32, 1056-1076. [CrossRef]

58. Kuvan, Y.; Akan, P. Residents' attitudes toward general and forest-related impacts of tourism: The case of Belek, Antalya. Tour. Manag. 2005, 26, 691-706. [CrossRef]

59. Singh, S.; Bahadur, R. Environmental Impacts of Tourism: A Case Study of Jammu and Kashmir. Int. J. Res. Appl. Sci. Eng. Technol. 2018, 6, 860-875.

60. Grössling, S.; Hall, M.; Scott, D. Tourism and Water; Channel View Publications: Bristol, UK, 2015.

61. Lohchab, R.K. Socio-economic and environmental impacts of tourism at Bhimtal and its management. Ann. Agri-Bio Res. 2010, 15, 157-163.

62. Lo, M.C.; Ramayah, T.; Hui, H.L.H. Rural Communities Perceptions and Attitudes towards Environment Tourism Development. J. Sustain. Dev. 2014, 7, 84-94. [CrossRef]

63. Garau-Vadell, J.B.; Díaz-Armas, R.; Gutierrez-Taño, D. Residents' perceptions of tourism impacts on island destinations: A Comparative Analysis. Int. J. Tour. Res. 2014, 16, 578-585. [CrossRef]

64. Naidoo, P.; Sharpley, R. Local perceptions of the relative contributions of enclave tourism and agritourism to community wellbeing: The case of Mauritius. J. Destin. Mark. Manag. 2015, 5, 16-25.

65. Pavel-Nedea, A.; Dona, I. Assessment of residents' attitudes towards tourism and his impact on communities in the Danube Delta. Econ. Eng. Agric. Rural Dev. 2017, 17, 275-280.

66. Honey, M. Ecotourism: Who Owns Paradise? 2nd ed.; Island Press: Washington, DC, USA, 2008.

67. Higham, J. Critical Issues in Eco-Tourism: Understanding a Complex Tourist Phenomenon; Oxford Elsevier: Amsterdam, The Netherlands, 2007.

68. Jafari, M.; Pour, S.A. Effects of economic, social and environmental factors of tourism on improvement of perceptions of local population about tourism: Kashan touristic city, Iran. Ayer 2014, 4, 72-84.

69. Zhao, J.; Li, S.M. The impact of tourism development on the environment in china. Acta Sci. Malays. 2018, 2, 1-4. [CrossRef]

70. Yumoto, T.; Matsuda, Y. Deer Eat World Heritage: Ecology of Deer and Forest; Bunichi Sōgō Shuppan: Tokyo, Japan, 2006.

(C) 2019 by the authors. Licensee MDPI, Basel, Switzerland. This article is an open access article distributed under the terms and conditions of the Creative Commons Attribution (CC BY) license (http://creativecommons.org/licenses/by/4.0/). 